\title{
Isolation of casein protein fractions
}

\author{
Zeynep Atamer ${ }^{1, a, *}$, Katharina Thienel ${ }^{1}$, Aline Holder ${ }^{1}$, Thomas Schubert $^{1}$, Remko Boom², \\ Jörg Hinrichs ${ }^{1}$ \\ ${ }^{1}$ University of Hohenheim, Institute of Food Science and Biotechnology, Department of Soft Matter \\ Science and Dairy Technology, Garbenstr. 21, D-70599 Stuttgart, Germany \\ ${ }^{2}$ Wageningen University, Laboratory of Food Process Engineering, P.O. Box 17, 6700 AA, \\ Wageningen, Netherlands \\ a.zeynep.atamer@uni-hohenheim.de \\ *corresponding author
}

Keywords: $\quad$ Dairy, milk proteins, isolation process, casein fractions

\begin{abstract}
The fractions of caseins ( $\breve{-}-, \quad 6$ - and $ə$ ) are widely used in food applications due to their physiochemical properties as well as their bio- and techno-functional properties. Especially, b-casein fraction is a precursor having a variety of bioactive peptides such as antihypertensive and opioid. Different methods have been established in isolating and purifying the casein fractions, particularly on 6-casein isolation. However, the obtained yield for each fraction still requires further improvement. The aim of this study was to increase the yield and purity of the fractions by constructing a set of experiments on technical scale and determining the main process parameters. Based on our previous studies on laboratory scale, a method for the technical scale isolation of casein fractions from micellar casein powder was developed. A comparable yield and purity values for 6-casein were obtained.
\end{abstract}

\section{Introduction}

Bovine milk constitutes two main proteins, casein and serum (whey) proteins. Casein is the major fraction and constitutes about $80 \%$ of the total protein. Bovine casein consists of four individual types of casein molecules: $\breve{S}_{1-}(\sim 38 \%), \breve{U}_{22}-(\sim 10 \%), \mathrm{b}-(\sim 34 \%)$, and ə-caseins $(\sim 15 \%)$ [1]. Caseins are widely used in food and non-food applications. They have various important technofunctional properties such as solubility, emulsification, foam formation and stabilization, waterbinding, gelation, heat and acid stability [2-4]. They also play an important role in non-food applications such as the production of plastic materials [5], textile fibers [6] and glues [7].

Recently, interest in pure casein fractions, especially b-casein, has grown. b-casein has good emulsifying and foam stabilizing properties because of its amphiphilic structure [8]. Ǔs-casein has ends with hydrophobic regions, whereas in the middle a hydrophilic region [9]. Due to this structural establishment, U⿱s-casein can also be used as structure formers such as stabilizers.

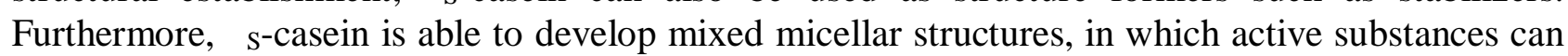
be entrapped [10]. ə-casein is a source of physiologically active compounds, caseinomacropeptides, which occurs during hydrolysis of 2 -casein with chymosin [11]. Caseinomacropeptides contain no 
phenylalanine in their amino acid sequence, making tehm suitable as a protein source for phenylketonuria patients [12].

Since the beginning of $1950 \mathrm{~s}$, several methods, either at small or large scale, have been developed for the isolation of casein fractions, especially b-casein [13]. Some of the pioneering work involves ion-exchange chromatography [14], electrophoresis [15], selective precipitation [16], gel chromatography [17] and liquid chromatography [18]. The processes for the isolation of the fractions use mainly selective solubility and precipitation as well as cross flow membrane filtration (microfiltration and ultrafiltration) [13]. Considerable progress has been made in isolating and purifying $\mathrm{b}$-casein. By applying a small-scale separation with a process volume of $5 \mathrm{~L}$, a $\mathrm{b}$ casein purity of $90 \%$, a yield of $10 \%$, and a corresponding recovery of $22 \%$ were achieved [19]. Technically fractionated caseins, to be applied in infant-formula, sport drinks or clinical nutrition are of special economic interest. Although numerous methods had been proposed, their technical recovery with a high purity and yield has not been realized. This study, therefore, aimed to further investigate the isolation method of casein fractions and to improve the isolation method.

\section{Materials and Methods}

\subsection{Production of micellar casein}

The micellar casein powder was produced using the method presented by Kersten [20]. In the method a combination of microfiltration and diafiltration was used. The skim milk (fat content: $<0.1 \%$ ) was concentrated using microfiltration (membrane: Membralox 3272 6C, $0.1 \mathrm{\varepsilon m}$, Pall Corporation, Bazet, France) at a constant temperature of $50{ }^{\circ} \mathrm{C}$. Afterwards, a diafiltration process was applied using ultrafiltration permeate, which was produced from sweet whey powder (Bayolan PT, BMI, Landshut, Germany). The obtained concentrate was spray dried and the micellar casein powder was used for the fractionation experiments.

\subsection{Isolation of the casein fractions}

The methods of Law and Leaver [21] and Post and Hinrichs [19] were optimized to obtain the food-grade 6 -casein as well as the other two casein fractions, $\breve{u}_{s}$ and $\partial$-casein. The calcium sensitive fractions, $\breve{U}_{-}$- and $\overleftarrow{6}$-casein, were precipitated by calcium chloride $(50-100 \mathrm{mM})$ and then separated by centrifugation (at $3000 \mathrm{~g}$ for $10 \mathrm{~min}$ at $20^{\circ} \mathrm{C}$ ). The main steps of the fractionation process are illustrated in Figure 1. The influence of the two main process parameters, $\mathrm{CaCl}_{2}$ concentration and $\mathrm{pH}$ value, on the isolation method were investigated in detail in a range varying from 10 to $50 \mathrm{CaCl}_{2} \mathrm{mmol} / \mathrm{L}$ and from 4.0 to 4.6 , respectively.

\subsection{Analysis}

For calculating the total protein content the nitrogen content was determined according to the Dumas method (Leco FP-528, Leco Instrumente GmbH, München-Gladbach, Germany) and was multiplied by conversion factor of 6.38 for milk and milk products [22]. The calcium content was determined according to VDLUFA IV C 10.6 .8 [22] by complexometric titration. While the dry matter was analyzed according to VDLUFA IV C 35.6 [22]. The lactose content was determined using infrared measurements according to IDF Standard 141C:2000 (LactoScope FTIR Advanced FTA-3.0, Delta Instruments, Drachten, Nederland) [23]. Fat content was determined using the gravimetric method according to Weibull-Stoldt (VDLUFA VI C 15.2.3) [22].

Selectively isolated casein fractions were analyzed by reverse-phase high-performance liquid chromatography (RP-HPLC) using an Agilent Technologies 1200 System and separated on a PLRP- 
S analytical column (150 x $4.6 \mathrm{~mm}, 300 \mathrm{~A}, 8 \mathrm{\varepsilon m}$ Agilent Technologies) under gradient conditions according to Post [24].

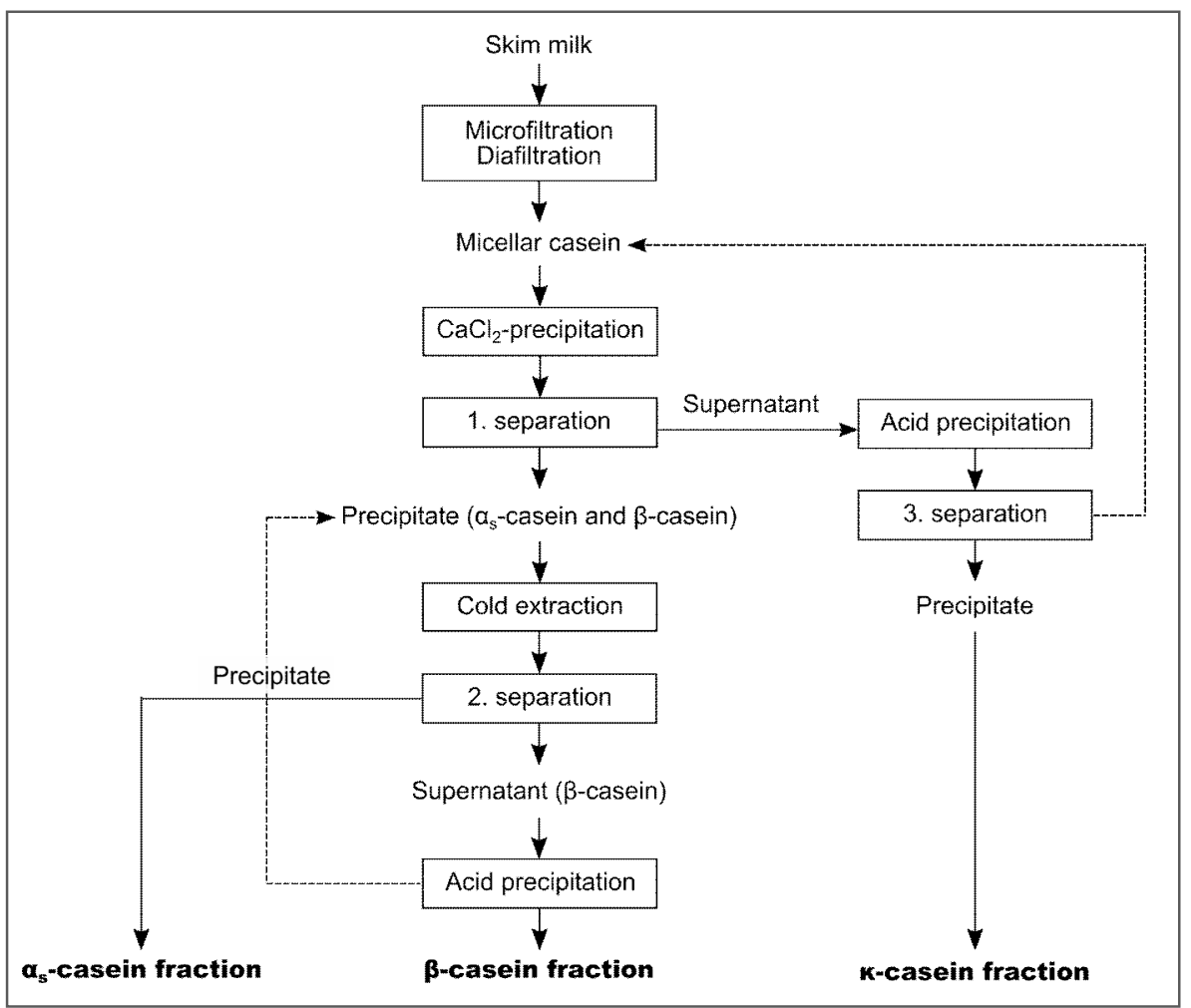

Figure 1: The main steps for the technical recovery of different casein fractions.

\subsection{Calculations}

The purity of a single casein fraction $\left(\mathrm{P}_{\mathrm{n}-\mathrm{CN}}\right.$; in \%) was defined as the ratio of the single casein fraction content $\left(\mathrm{c}_{\mathrm{n}-\mathrm{CN}}\right.$, fraction $)$ and the total casein concentration in total ( $\left.\mathrm{c}_{\text {total casein }}\right)$ (Eq. 1).

$$
\mathrm{P}_{\mathrm{n}-\mathrm{CN}}=\left(\mathrm{c}_{\mathrm{n}-\mathrm{CN}, \text { fraction }} / \mathrm{c}_{\text {total casein }}\right) * 100
$$

The yield ( $\mathrm{Y}_{\mathrm{n}-\mathrm{CN}}$; in \%) of each casein fraction is calculated using Eq. 2:

$$
\mathrm{Y}_{\mathrm{n}-\mathrm{CN}}=\left(\mathrm{m}_{\mathrm{total} \mathrm{CN}} * \mathrm{P}_{\mathrm{n}-\mathrm{CN}}\right) /\left(\mathrm{m}_{\mathrm{MCN}} * \mathrm{c}_{\text {total protein, } \mathrm{MCN}}\right) * 100
$$

where $\mathrm{m}_{\mathrm{total}, \mathrm{CN}}$ refers to the mass of the obtained $\mathrm{n}$-casein fraction, $\mathrm{m}_{\mathrm{MCN}}$ to the initial mass of

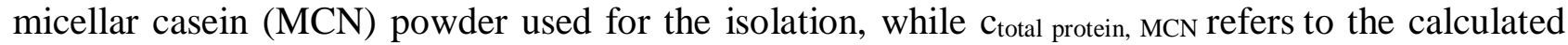
protein content of the micellar casein using the measured the nitrogen content.

The recovery $\left(\mathrm{R}_{\mathrm{n}-\mathrm{CN}}\right)$ of each casein fraction is calculated according to

$$
\mathrm{R}_{\mathrm{n}-\mathrm{CN}}=\left(\mathrm{Y}_{\mathrm{n}-\mathrm{CN}, \text { fraction }} / \mathrm{c}_{\mathrm{n}-\mathrm{CN}, \mathrm{MCN}}\right) * 100
$$

where $\mathrm{c}_{\mathrm{n}-\mathrm{CN}}$, MCN was defined as the analyzed $\mathrm{n}$-casein concentration of the micellar casein powder using reversed-phase high performance liquid chromatography. 


\section{Results and Discussion}

The chemical composition of the micellar casein powder is given in Table 1 . The obtained micellar casein powder is almost free from whey proteins $(0.2 \%, \mathrm{w} / \mathrm{w})$ and contained the three casein fractions ( $\breve{U}_{-}, \underline{b}$-, and $ə$-casein). The casein to total protein ratio in the powder was calculated to be $91 \%$. The obtained chemical composition of the micellar casein powder is similar when compared to the previously obtained powder composition [24].

Table 1: Chemical composition of micellar casein powder (mean of triplicate analysis).

\begin{tabular}{|c|c|}
\hline Main component & Composition $(\%, \mathrm{w} / \mathrm{w})$ \\
\hline Dry matter & $96.6 \pm 0.2$ \\
\hline Calcium & $2.08 \pm 0.04$ \\
\hline Lactose & $18.6 \pm 0.2$ \\
\hline Fat & $2.4 \pm 0.2$ \\
\hline Casein/Total protein & 91.1 \\
\hline Whey protein & $0.2 \pm 0.1$ \\
\hline
\end{tabular}

Skim milk is used for the extraction of casein. This can be done by applying a purely physical process or a combination of physical and biochemical processes [13]. Examples of the applied methods are namely: (i) precipitation by rennet (rennet-casein) [25], by mineral acids such as hydrochloric or sulphuric acid (mineral acid-casein) [16] or using a lactic starter (lactic acid-casein) [15] and (ii) separation using a membrane filtration process such as microfiltration [26]. In this study, for the production of casein, a cross-flow membrane filtration process was used to obtain micellar casein concentrate. In comparison to other chemical and thermal processes applied for the separation of the individual fractions [13], no modification of the casein micelles occurs and the functional characteristics of the casein protein does not change [27]. Therefore, caseins obtained by using this method can be considered as ñativeò.
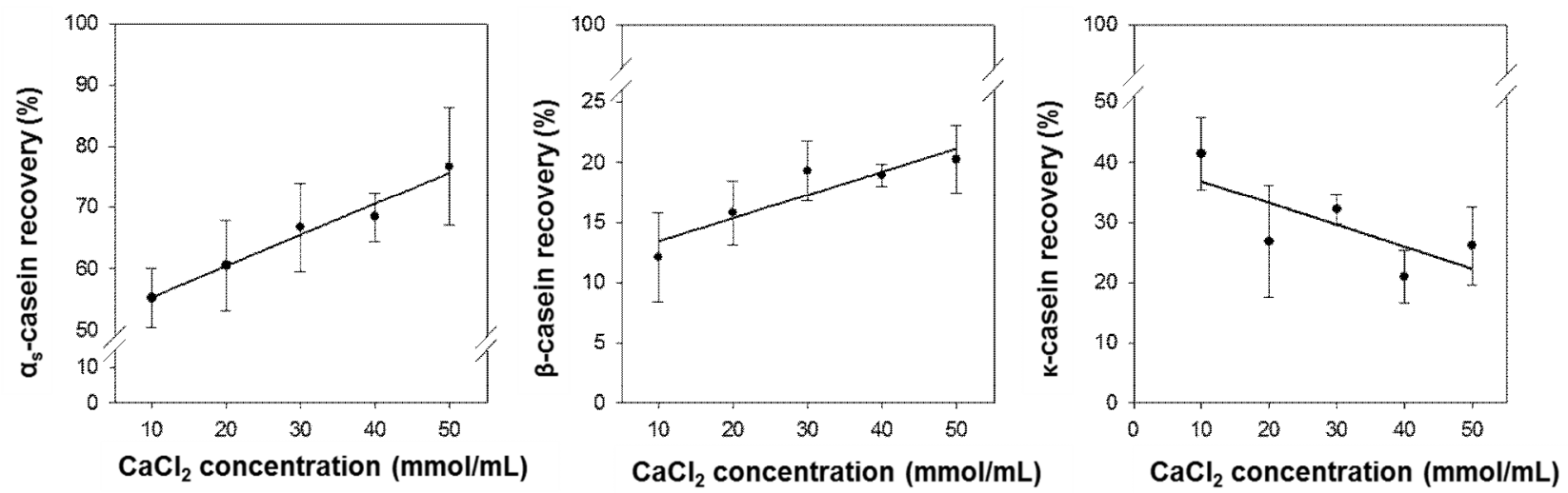

Figure 2: Recovery values of 6 -, $\breve{U}_{-}$, and $ə$-casein fractions depending on the $\mathrm{CaCl}_{2}$ concentration used for the precipitation of $\breve{U}_{-}$and $\mathbf{b}$-caseins in Figure 1.

For the fractionation of the caseins, the calcium sensitive $\breve{U}_{s-}$ and $\mathrm{b}$-caseins were precipitated by addition of $\mathrm{CaCl}_{2}$-solution. The final calcium concentration were varied in the range of between 10 and $50 \mathrm{CaCl}_{2} \mathrm{mmol} / \mathrm{L}$ in order to investigate the influence of the calcium concentration on the isolation method. The dependency of each fraction to the applied calcium concentration in the fractionation process are illustrated in Figure 2. Variation of the $\mathrm{CaCl}_{2}$ concentration had an 
influence on the purity and recovery of any casein fraction. Similarly, the effect of the $\mathrm{pH}$ on the isolation of $\breve{L}_{5-}$ and $\mathrm{b}$-casein fractions can be depicted in Figure 3.
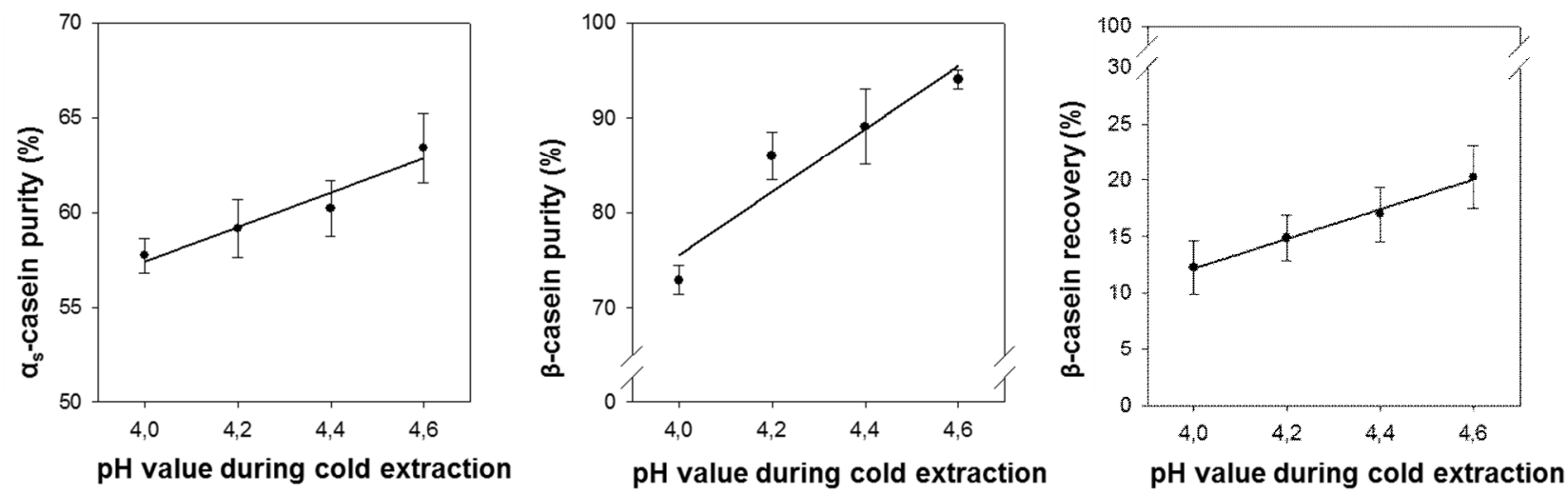

Figure 3: Purity values of $\breve{U}$ - and 6 -casein and recovery of 6 -casein fractions depending different $\mathrm{pH}$ values used in the cold extraction.

Figure 4 shows the example chromatographic profiles obtained in this study. The

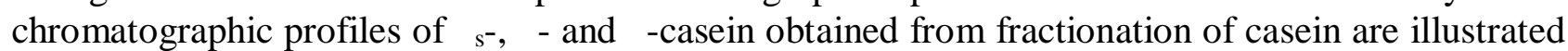
together with the profile of micellar casein. A high purity achieving a value of $90 \%$ could be obtained for the $\mathrm{b}$-casein fraction at a large process scale. The obtained purity value was in close agreement with the results previously reported at small process scales $[19,24,28]$. Using the method proposed in Figure 1, a higher yield was achieved for the b-casein fraction.

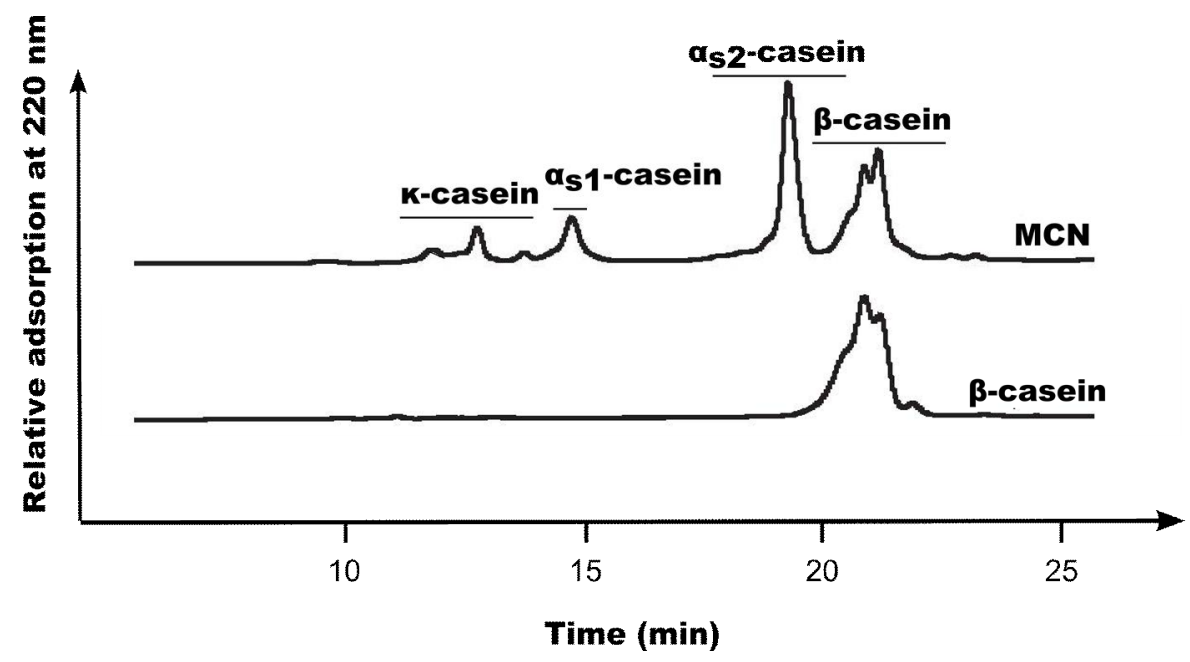

Figure 4: Chromatographic profiles of micellar casein $(\mathrm{MCN})$ and $\mathrm{b}$-casein obtained from fractionation process according to the method illustrated in Figure 1.

\section{Conclusions}

Isolation of individual casein fraction is of growing interest due to their multifunctional applications and clean-label status. Although various isolation and purification methods of casein fractions have been reported, there is still a need of improvement for their isolation, especially on a technical scale. Using micellar casein obtained with the help of a membrane filtration separation process, highly 
purified b-casein fractions can be gained at a technical scale using the proposed method outlined in this study. The process enables achieving higher yields for 6 -casein fractions. This process leads to highly enriched soluble $\breve{U}_{-}$and ə-casein fractions. The main two process parameters, the $\mathrm{CaCl}_{2}$ concentration applied for the precipitation and the $\mathrm{pH}$ value used during cold extraction, have an influence on the isolation of the individual fractions. Further work is in progress to optimize the two fractions of $\breve{U}_{-}$and ə-casein.

\section{Acknowledgements}

This research project was supported by the German Ministry of Economics and Technology (via $\mathrm{AiF}$ ) and the FEI (Forschungskreis der Ernährungsindustrie e.V., Bonn). Project AiF 17126 N.

\section{References}

[1] Dalgleish, D.G., Corredig, M. (2012) The structure of the casein micelle of milk and its changes during processing. Annu. Rev. Food Sci. Technol., 3, 449-467.

[2] Broyard, C., Gaucheron, F. (2015) Modifications of structures and functions of caseins: a scientific and technological challenge. Dairy Sci. Technol., 95, 831-862.

[3] Munro, P.A. (2002) Milk Proteins. Caseins, Functional Properties and Food Uses. in: Encyclopedia of Dairy Sciences, Elsevier, Oxford, pp. 1909-1915.

[4] Singh, H. (2002) Milk Proteins. Functional Properties. in: Encyclopedia of Dairy Sciences, Elsevier, Oxford, pp. 1976-1982.

[5] Brother, G.H. (1927) Casein plastics. in: Sutermeister, E. (Ed.) Casein and its industrial applications, The Chemical Catalog Company, Inc., New York.

[6] Schwis, P., Hänssler, S., Hinrichs, J. (2013) Extrusion von Casein zur "Milchfaser". Moproweb, 38-41.

[7] Browne, F.L. (1927) Casein glue. in: Sutermeister, E. (Ed.) Casein and its industrial applications, The Chemical Catalog Company, Inc., New York.

[8] Dickinson, E. (2003) Interfacial, emulsifying and foaming properties of milk proteins. in: Fox, P.F., McSweeney, P.L.H. (Eds.) Advanced dairy chemistry - 1: Proteins, Kluwer Academic/ Plenum Publishers, New York, pp. 1229-1260.

[9] Murphy, J.M., Fox, P.F. (1991) Functional properties of or $\beta$-rich casein fractions. Food Chem., 39, $211-228$.

[10] Kessler, A., Menéndez-Aguirre, O., Hinrichs, J., Stubenrauch, C., Weiss, J. (2013) Ǔ-Casein-PE6400 mixtures: A fluorescence study. Faraday Discuss., 166, 399-416.

[11] Brody, E.P. (2000) Biological activities of bovine glycomacropeptide. Br. J. Nutr., 84.

[12] Korhonen, H.J. (2009) Bioactive milk proteins and peptides: From science to functional applications. Aust. J. Dairy Tech., 64, 16-25.

[13] Atamer, Z., Post, A.E., Schubert, T., Holder, A., Boom, R.M., Hinrichs, J. (2017) Bovine 6-casein: Isolation, properties and functionality. A review. Int. Dairy J., 66, 115-125.

[14] Thompson, M.P. (1966) DEAE-cellulose-urea chromatography of casein in the presence of 2-mercaptoethanol. J. Dairy Sci., 49, 792-795.

[15] Maubois, J.L. (1984) Separation, extraction and fractionation of milk protein components. Lait, 64, $485-495$.

[16] Hipp, N.J., Groves, M.L., Custer, J.H., McMeekin, T.L. (1952) Separation of $\alpha$-, $\beta$-and $\gamma$-casein. J. Dairy Sci., 35 , $272-281$.

[17] Nakahori, C., Nakai, S. (1972) Fractionation of caseins directly from skimmilk by gel chromatography. 1. elution with sodium dodecysulfate. J. Dairy Sci., 55, 25-29.

[18] Ng-Kwai-Hang, K.F., Chin, D. (1994) Semipreperative Isolation of Bovine Caseine Components by High Performance Liquid Chromatography. Int. Dairy J., 4, 99-110.

[19] Post, A.E., Hinrichs, J. (2011) Large-scale isolation of food-grade $\beta$-casein. Milchwissenschaft, 66, $361-364$.

[20] Kersten, M. (2001) Proteinfraktionierung mittels Membrantrennverfahren [Protein fractionation by means of membrane processing]. PhD Thesis. in, Technical University of Munich, Munich, Germany.

[21] Law, A.J.R., Leaver, J. (2007) Methods of extracting casein fractions from milk and caseinates and production of novel products. in, Hanna Research Institute, WO.

[22] VDLUFA (1985) Methodenbuch Band VI - chemische, physikalische und mikrobiologische Untersuchungsverfahren für Milch, Milchprodukte und Molkereihilfsstoffe (6. Ergänzungslieferung 2003). VDLUFAVerlag, Bonn. 
[23] IDF (2000) Whole milk: Determination of milkfat, protein and lactose content ï guidance on the operation of midinfrared instruments. IDF Standard 141C:2000,. Int. Dairy Fed., Brussels, Belgium.

[24] Post, A.E., Ebert, M., Hinrichs, J. (2009) 6-casein as a bioactive precursor - processing for purification. Aust. J. Dairy Tech., 64, 84-88.

[25] Huppertz, T., Hennebel, J.-B., Considine, T., Shakeel-Ur-Rehman, Kelly, A.L., Fox, P.F. (2006) A method for the large-scale isolation of b-casein. Food Chem., 99, 45-50.

[26] van Hekken, D.L., Holsinger, V.H. (2000) Use of cold microfiltration to produce unique 6-casein enriched milk gels. Lait, 80, 69-76.

[27] Post, A.E. (2011) Fractionation of bovine casein and enrichment of functional casein peptides. in, University of Hohenheim, Dr. Hut, Stuttgart, Germany.

[28] Post, A.E., Hinrichs, J. (2010) Suitability of commercial caseinates in comparison to micellar casein as raw material for isolation of food-grade $\beta$-casein. Milchwissenschaft, 65, 195-198. 